\title{
LAND DEVELOPMENT IN NEW ZEALAND - CASE STUDIES ON THE IMPORTANCE OF SITE SELECTION, DUE DILIGENCE, FINANCE AND THE REGULATORY ENVIRONMENT
}

\author{
JOHN McDONAGH \\ Lincoln University
}

\section{ABSTRACT}

This research investigated critical factors that contribute to the success of residential land development in New Zealand. The methodology involved determining those factors identified as critical by international researchers and then drawing comparisons to critical factors identified in interviews with various members of four property development teams active in New Zealand. This paper focuses on factors associated with the site itself. The findings presented here include the concept of "success" in New Zealand is centered on profitability, timeframes and budgets. There was a greater focus on the due diligence phase, at the expense of the site selection phase, compared with earlier research. There were also fewer options available for financing property development in the New Zealand context. The development legislation was generally seen as appropriate, but its application was felt to be inconsistent and the source of much of the risk in a property development. While the critical factors identified were similar to those found in the literature, there was a much greater reliance on experience to manage their impact than on the more formal approaches employed in other countries.

Keywords: development, subdivision, residential, success factors, site selection, due diligence, resource management, regulatory environment, development finance

\section{INTRODUCTION}

The development of raw land into lots suitable for construction of individual houses is a lengthy and complex process. It is also a topical one in New Zealand, with debate in recent times regarding the high cost of land for housing relative to the actual cost of house construction. The purpose of this research was to investigate the critical factors that contribute to the success of residential land development in New Zealand.

The research involved two phases; the first was a literature review to establish a theoretical view of elements or factors important to the land development process. The second stage was to test if this model reflected reality in a New Zealand context 
via interviews with various members of development teams from four case study residential land development projects.

Because of the range of responses collected and the desire to keep this paper to a reasonable length, the research has been divided into two "themes". The first, and subject of this paper, are those success factors most associated with the project itself. These include site selection, due diligence, finance and the regulatory environment.

\section{LITERATURE REVIEW}

This research was primarily concerned with the development of large blocks of residential and rural residential land into lots suitable for the construction of residential dwellings. In New Zealand, "subdivision" is often used generically to describe this process which is more accurately described as a residential land "development". Christensen (1996) describes the typical land development as follows:

"The complete development process of carrying subdivisions beyond their technical stage to the provision of underground services, tailoring the service of the land and construction thereon of streets, footpaths, complete with curbs and channels, street lighting, trees, grass burns, street names and most importantly, sections with legal title and building platforms capable of being built on.”

Christensen also provides a flowchart of this "subdivision” process from a procedural prospective from which it is apparent that it is a complex process and must be carefully planned at all times. Searches of academic databases found almost no other research on land development in a New Zealand context. There were a small number of papers describing reforms of the regulatory processes that were associated with the introduction of the Resource Management Act, but none of these considered criticality from a developer's perspective. The critical success factors were therefore initially identified from the international literature available to the researcher at the time the research was carried out.

\section{General rules for success}

Dowell (1989) provides the following general criteria for a successful land development project:

- $\quad$ Clear and simple goals,

- Incorporate incentives which reward performance and risk taking,

- Be small in size,

- $\quad$ Be flexible and responsive to changing market conditions, and;

- $\quad$ Have access to sufficient financial resources and highly talented staff. 
It could be argued that large land developments can be successful with effective planning, but in these cases it is also difficult to satisfy the criteria of retaining flexibility. This is particularly the case as local authorities usually require a detailed plan of the ultimate form of the development prior to granting approval. Developments completed in "stages" are a common response to these problems.

Peiser and Schwanke (1992) recommend that market research should consider existing competition plus levels of supply which may become available during the term of the development. They also offer general advice that can be applied to all development situations - "be well prepared at all times, work with experienced people, and anticipate delays throughout the development process”.

Waterhouse (1991) also offers general advice - "successful development and the ability to avoid catastrophic error are not so much a matter of having a particular depth of knowledge in one or more fields, you can hire experts to provide that, but rather than having a breath of knowledge about the development process and the willingness to be methodical and attentive to detail”.

\section{Site selection}

The selection of an appropriate parcel of land is dependant on a variety of factors which include market supply and demand for residential sections, the urban growth patterns pertinent to the location under consideration, regulatory and zoning considerations and the location itself including any physical aspects of the land.

Sorenson (1990) suggests demographic information including; market statistics, population base, population density, projected growth, growth patterns and household incomes relevant to the project should be researched and future market ramifications analysed. Also to be taken into account are; existing competition, accessibility, traffic patterns, the desirability of the location and ensure proposed uses are compatible with the environment. Sorenson also makes the comment "Economic warning signs are always there but are often overlooked as those involved in real estate development tend to get caught up in the mood of the times". Sorenson also notes "good timing, whether caused by good luck or superior economic forecasting skills, can make a success out of an otherwise mediocre project.

Researching urban growth patterns is considered in more detail by Martin (1984). Accessibility and linkage are considered critical. This includes accessibility to amenities such as shopping centres, places of employment, schools etc. The availability of arterial roads as well as public and commercial transportation systems will encourage growth. Urban growth can also be influenced by physical features including rivers, harbours and steep terrain. Such features can constrain urban growth for some uses, but can also promote it due to the relative attractiveness of those features. 
Where there are major commercial or industrial developments, this usually creates demand for residential areas within reasonable proximity and this may trigger residential activity in previously inactive locations.

The developer must make contact at a very early stage with regularity authorities and assess their attitudes towards a proposed development. The more land a developer can obtain in an area of potential growth, the more options that may be available. If there is limited suitable land, it is more likely that the local authority will require more intensive development of that land and restrictions may be more onerous.

Pearson (1991) also considers many of the site selection ideas put forward by Martin but divides them into two categories; micro-location and macro-location. Under micro-location, linkages and externalities are considered. The former reflect the thinking of Martin but also include utility linkages. Externalities include the actions of persons or institutions that may affect the welfare of others in ways that cannot be regulated by private agreements among those parties. These include such things as arterial routes going through areas of high crime, nearby industrial plants and other both positive and negative manmade externalities. An example of positive externalities may be bush areas, attractive views or natural amenities such as rivers or lakes. The macro-location category is more relevant to large scale developments where the patterns of urban growth and economic base of a region become relevant.

Hiemlich and Anderson (2001), suggest land use change and growth patterns can predictably be attributed to population growth, household formation and economic development. They maintain that changes in land use are the end result of forces driven by millions of separate choices made by homeowners, farmers, business and government. They maintain that large metropolitan areas grow organically following well known stages of growth.

Arrow International (undated) lists the following matters to being assessed during site selection:

- Zoning encumberances and legal constraints,

- Location, transport systems, travel flow and access,

- Quality and location of services,

- Profile, and;

- Geographical characteristics.

Dowell (1989) lists the following:

- Identification of sites available for sale.

- Determination of housing demand by type of product, price range and location. 
- Assessment of supply of housing and finished residential plots by type and size, price range and location.

- Protection of future demand and supply given mortgage interest rates, employment, population growth and overall economic outlook.

- Assessment of current land use patterns and development controls.

- Selection of sites that offer the most attractive risk adjusted profit.

Peiser and Schwanke (1992) Waterhouse (1991) also provide further advice on site selection. But their lists are very similar to that of Arrow International above.

\section{Due diligence}

While primary investigations will usually have been carried out during site selection, the next stage of investigation will usually require the detailed input of consultants and other experts. This is often commonly called due diligence or feasibility.

Dowell (1989) describes aspects to research once a property has been conditionally secured. These include assessment of the availability of services, preliminary physical assessment to determine development potential, checking with public agencies regarding zoning, land use and other sub-divisional controls and estimating land and housing development costs for each site. Based on the costs of the above, the selling prices and take-up rate, an estimate of preliminary profit level and development risks for the site can be made.

Christensen (1996) focuses more on the idea of feasibility study as does Jarchow (1991) who defines this as "a generic term which groups together a variety of predevelopment studies by journalists and specialists in a systematic philosophy of inquiry to determine facts that are reliable, assumptions about the future that are consistent with past experiences and tactics which will minimise the variance”.

Christiansen (1996) recommends the following be included in any full feasibility study:

- Introductory statement

- Site description

- Statutory constraints

- Market research

- Development proposals/options

- Possible designs

- Special features

- Financial feasibility

- Conclusions and recommendations

Arrow International (undated) sets out the following items for detailed investigation: 
- Conceptual planning layouts

- Preliminary costs estimates

- Preliminary financial feasibility analysis

- Project risk assessment

- Programme assessment

Sorenson (1990) emphasizes the importance of research into physical characteristics focusing on size, soil analysis, topography, frontage, utilities and zoning. Other elements should also be considered; "the existence of hazardous waste problems, floodplains, or seismic fault lines for example, can override the economic benefit of an otherwise desirable site".

Sorenson also states certain costs may not become evident until the development is well under way. Costs may also increase because of unforeseen delays due to "increased interest rate volatility, large fluctuations in construction costs and government involvement”. Confidence in projections is only derived from quality and reliable data because "forecasting is an imprecise art at best and projected cash flows if not carefully prepared can result in totally misleading forecast” (Sorenson, 1990).

It is during this conditional period that the developer should also turn their thoughts to other factors including options for financing and ownership structure. Account should taken of cash requirements for deposits and settlement date (final payment) as well as structures which minimize tax, risk and liabilities to the individuals involved with the development. In most cases, this will require input from suitably qualified legal advisors and accountants prior to finalization of the acquisition.

\section{Development financing}

Most developers will require financing in some form or another and these funds can come from a variety of different sources. Rowland (1993) divides these into two broad categories being debt and equity finance, and further divides each of these into "project finance" and ongoing "corporate finance". In the case of land development, project finance is usually the concern.

Peiser and Schwanke (1992) list financial institutions that could provide development funding as commercial banks, savings and loan institutions, insurance companies, pension funds, foreign investors, syndications and real estate investment trusts (REITS), private investors and joint ventures. Gitman et al (1995), Damodaran (2001) and Rowland (1993) all describe the characteristics of debt financing and the dominance of banks in this area. However, Rowland comments on the emergence of other sources of debt finance for development over the last 40 years and how this has waxed and waned. The complexity of development finance arrangements are also 
discussed by Rowland, and Loh (2003) and Bank of America (2002) outline the characteristics of mezzanine finance and how this can be useful to developers.

Equity financing is also discussed by Peiser and Schwanke (1992), Rowland (1993) and Geurard (2005). The complexity of possible arrangements and the effect on risk of the debt/equity balance is a focus for these authors. Joint ventures and syndications are also discussed.

The literature revealed there are a number of options when financing a land development project. Which options a developer may use to fund a project comes down to a number of factors including the strength of the project, relationships with lenders, the security that can be offered and the debt servicing ability of the borrower. If lenders have a positive attitude towards development in a particular area, then the cost of finance and availability are likely to be more favourable than if they have the opposite point of view. A developer who is relatively new to the industry may have fewer options than a well established development company with strong lending relationships and a strong financial base. The cost of financing will generally be higher until the abovementioned factors can be further enhanced through experience and time. The right financing mix, how much profit is given away to lenders and the ability to adhere to lending covenants appear to be critical to the success of a typical land development.

The relationship between time and financing can be the death knell for many developments.

"Rising interest rates can sound a death knell for leveraged real estate, particularly for those undercapitalized or over leveraged projects that face financial difficulties when unanticipated adverse conditions occur" (Sorenson, 1990). "Time permits the power of compound interest to erode the developer's resources, and it allows the conditions of competition and consumer needs which were true when the project started to change significantly" Jarchow (1991).

\section{Legislation and the regulatory process}

The primary legislation that governs land development in New Zealand is the Resource Management Act 1991 (RMA). This sets out the legal process by which consents are granted allowing property developments to progress. "Sustainable Management is defined in the RMA as meaning the use, development and protection of natural and physical resources" (Crosby, 1994)

All subdivisions require a resource consent to be granted by the local authority; "Whether this application is for a controlled, discretionary or non-complying activity, and whether it is processed as a notified or non-notified application will depend on the size and circumstances of the proposed subdivision, and the provisions of the local 
authority's district plan" (Christiansen, 1996). Christiansen also provides a useful flow chart which maps out the complex resource consent process as it relates to the RMA.

"It is important to make a preliminary planning assessment of a project at an early stage, well before any design work commences. A properly prepared preliminary assessment will highlight the resource management issues that need to be resolved" (Rae, 1999). Rae also recommends consultation as being an essential component of the consent process; "Consultation is an essential component of the resource management process, as the RMA places greater emphasis on consultation prior to consent applications being lodged". "Developers should adopt a strategic approach by integrating the RMA framework as part of their strategy rather than something that should be fought over after a project is designed" (Rae, 1999, p.50).

Obtaining a favorable resource consent appears to be a critical success factor in land development. The developer must use considerable financial resources to obtain competent advice from experienced professionals who have an excellent understanding of both the RMA and associated District and Regional Plans. It is also necessary to establish clear dialogue with the relevant local authority to ensure the requirements of both parties are clearly outlined. In large scale projects, the developer should allow for extended periods of time as there are often issues that will delay the consent process.

\section{RESEARCH METHODOLOGY}

The first stage of the research involved compiling a review of the literature to help identify factors in the land development process that contribute to success. Those identified can be summarized as: site selection, due diligence, finance, the regulatory environment, development planning, team member selection, project management and sales and marketing. As mentioned earlier, only the first four factors of the preceding list are considered here.

The second stage of the research was to investigate whether these factors are considered essential to success in a New Zealand context. This involved a unique opportunity in 2006 to obtain in depth knowledge of processes and access to key personnel within one of the larger residential development firms in New Zealand. Four case study projects were investigated in depth and 30 individuals surveyed/interviewed. These cases were not randomly selected and there is obviously a significant risk of not getting a true reflection of industry practices with such a small and biased sample. However, this was the only option available to the researchers at the time and appears to be the only research of this type undertaken to date in New Zealand. It should therefore be seen as exploratory research and care taken in generalizing from the results. 
Potential bias was mitigated by the fact that the four projects were situated in four very separate locations through out New Zealand and each had a completely separate development team. Each project was a joint venture arrangement and therefore influenced by different groups of shareholders who were not part of the principal development company. However the possibility still exists that the top management and overall culture of the larger organisation may have influenced the responses.

Details of each case study are provided in Table 1.

Table 1: Project case studies - general details

\begin{tabular}{|c|c|c|c|c|}
\hline & Project 1 & Project 2 & Project 3 & Project 4 \\
\hline Project type & Residential & $\begin{array}{l}\text { Rural- } \\
\text { Residential }\end{array}$ & $\begin{array}{l}\text { Rural- } \\
\text { Residential }\end{array}$ & $\begin{array}{l}\text { Rural- } \\
\text { Residential }\end{array}$ \\
\hline General Location & $\begin{array}{l}\text { Lower North } \\
\text { Island }\end{array}$ & $\begin{array}{l}\text { Lower North } \\
\text { Island }\end{array}$ & $\begin{array}{l}\text { Central North } \\
\text { Island }\end{array}$ & $\begin{array}{l}\text { Lower South } \\
\text { Island }\end{array}$ \\
\hline Lot yield & 28 Lots & 110 Lots & 181 Lots & 18 Lots \\
\hline Lot size $\left(\mathrm{m}^{2}\right)$ & 450 to 850 & $\begin{array}{l}4000 \\
10,000\end{array}$ & 700 to 10,000 & $\begin{array}{l}12,000 \\
24,000\end{array}$ \\
\hline $\begin{array}{l}\text { Project valuation } \\
\text { (GST Incl) } \\
\text { (on completion) }\end{array}$ & $\$ 9.3 m^{+}$ & $\$ 10 \mathrm{~m}+$ & $\$ 40 m+$ & $\$ 9.6 m^{+}$ \\
\hline Commencement & Early 2002 & Mid 2004 & Early 2003 & Mid 2004 \\
\hline Completion & Late 2005 & 2010 & 2009 & Mid 2007 \\
\hline
\end{tabular}

Thirty project team members were provided with a questionnaire to complete. Follow up phone calls, emails or interviews were often necessary for further clarification on answers.

For each critical factor identified in the literature review, questions were developed with the answer providing information for the comparison of theory against actual practice in the land development industry in New Zealand. The questionnaire contained simple "yes" or "no" questions, five point Likert scale questions and other questions which were more qualitative in nature requiring the respondent to provide written answers based on their opinion or experience.

Strengths and weaknesses respondents saw in each project were also identified and this provided evidence as to whether those factors identified as being critical to success in theory contributed to the level of project success and/or problems 
experienced in the projects. In addition, respondents provided general comments regarding their experiences in other projects they have been involved in.

A response rate across the four project case studies of 70\% was achieved with 21/30 questionnaires/interviews completed. Quantitative data was graphed or tabled and those questions that required a qualitative answer were further analysed to identify any trends apparent across the case studies.

\section{RESULTS}

Table 2: Mix and proportions of respondents

\begin{tabular}{lll}
\hline & Actual number & \% of total \\
\hline Shareholders & 8 & $38 \%$ \\
Management & 3 & $14 \%$ \\
Consultants & 10 & $48 \%$ \\
Other & 0 & $0 \%$ \\
Total & $\mathbf{2 1}$ & $\mathbf{1 0 0 \%}$ \\
\hline
\end{tabular}

\section{Measuring success}

In order to ascertain which elements are critical to success, it was important to first establish what "success" is to those being surveyed. To this end, respondents were asked to rate from 1 (being least important) to 5 (being most important), the elements which were considered relevant to the success of a development project.

\section{Figure 1: Importance of each element of success}

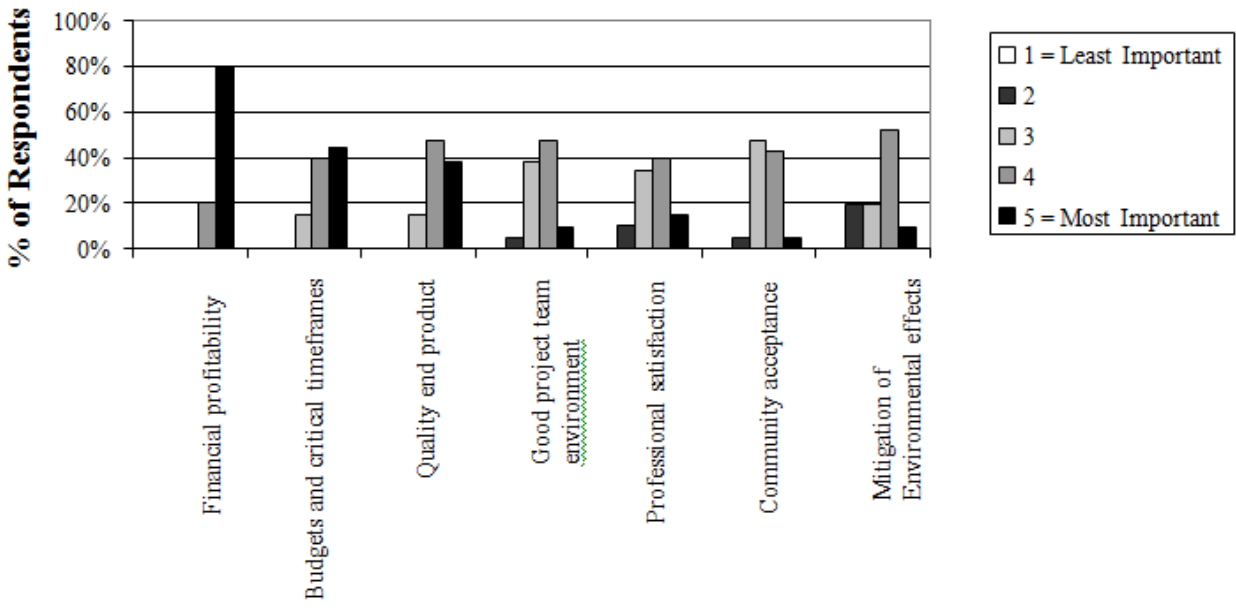


$80 \%$ of respondents rated financial profitability as being most important, with the remaining $20 \%$ giving this element a rating of 4 . The majority of respondents rated all elements as moderately to most important, with only a very small number rating any of the elements of little importance. Of these, professional satisfaction, community acceptance and mitigation of environmental effects received the lowest ratings proportionately.

The latter findings are surprising when the community can have a strong influence on especially the regulatory process. Further questioning suggested commercial reality means a balance must be found when attributing importance and thus resources to all of the aspects described above. For example, certain aspects such as critical financial and budget timeframes take priority over other aspects in order for a development to remain profitable for the principal company.

When asked whether all the above elements were achieved in a general sense; only $5 \%$ of respondents believed all were achieved and $81 \%$ believed some elements were achieved. $15 \%$ of respondents believed either very few or no elements defining success were achieved on their projects.

\section{Site selection}

Site selection concerns those preliminary investigations to establish whether a site has all the necessary factors conducive to a successful development. Figure 2 suggests the development teams have neglected this stage of the development process to a degree. However, this is qualified by noting that a number of issues often investigated during site selection may have instead been addressed during the due diligence stage.

\section{Figure 2: Extent of site selection investigation}

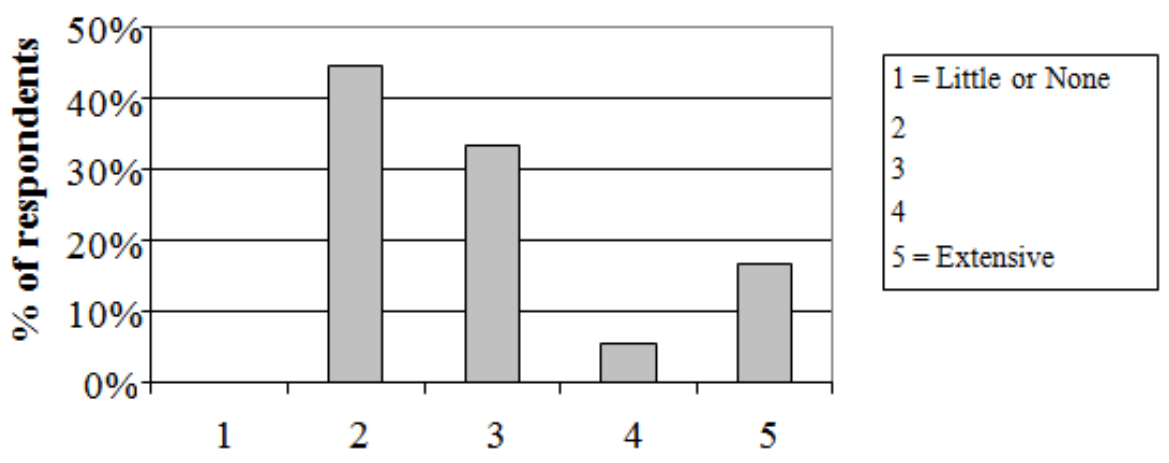

Ratings for extent of investigation 
$44 \%$ of respondents rated the extent of preliminary site selection investigations as being minimal; 33\% suggesting moderate investigations (rating of 3) were carried out and $7 \%$ rated the extent of investigations as being fairly detailed (rating of 4 ) . 17\% of respondents believed extensive site selection investigations were carried out.

Factors that were investigated during the site selection process included:

- $\quad$ Location - Potential market for finished product.

- Development cost estimates.

- Value of end product.

- Assessment of planning risks (including the current zoning).

- Assessment of design and construction risk.

- Accessibility.

- $\quad$ Existing site contamination.

- $\quad$ Availability and capacity of existing services including power, gas and telecommunications.

- $\quad$ Value added opportunities.

- $\quad$ Competition in the area.

- $\quad$ Proximity to major townships.

- Proximity to recreational facilities.

- $\quad$ Natural features and views.

- $\quad$ Price.

Figure 3 identifies the extent to which different sources of information for site selection were employed. Professionals were often used (61\%), with much less emphasis placed on preliminary discussions with local authorities, with only $8 \%$ of respondents suggesting extensive discussions were held. Very little regard has been given to statistical information, with $81 \%$ of respondents suggesting this was the least used or infrequently used source of information. In addition, $67 \%$ of respondents said that self assessment was used the most in the site selection process with the remaining $33 \%$ also suggesting this was used frequently. It was predominantly shareholders and managers who assessed a site based on their own experience and judgment. 


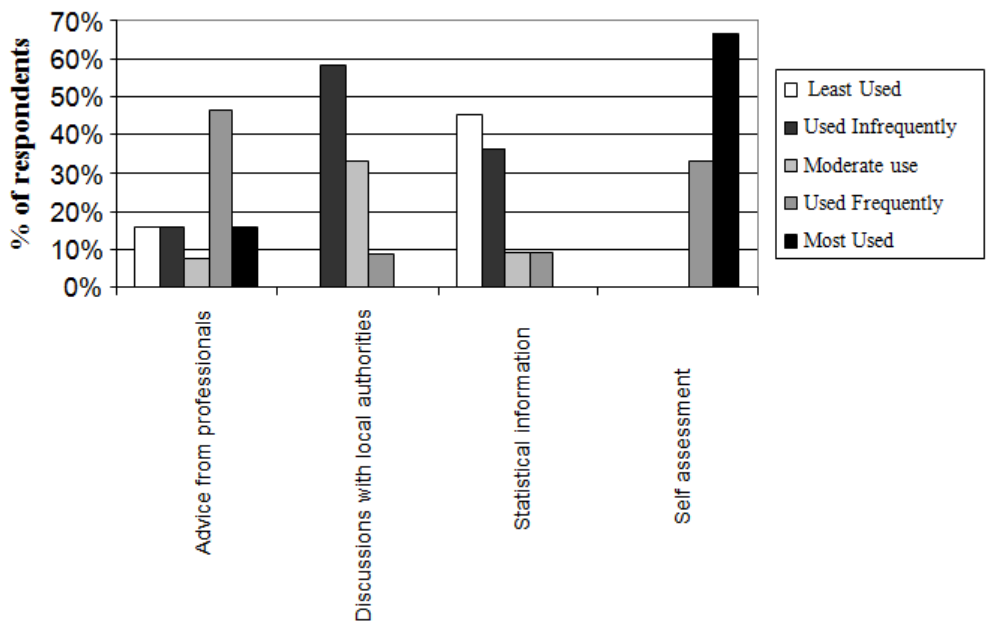

\section{Due diligence}

Similar to the site selection process, respondents were asked to rate the extent to which a due diligence process was carried out after the site had been secured. Figure 4 shows the results, with $35 \%$ of respondents believing extensive due diligence was carried out and $53 \%$ believing the due diligence carried out was moderate to fairly extensive. Only $12 \%$ believed due diligence was not carried out very extensively.

\section{Figure 4: Ratings for extent of due diligence}

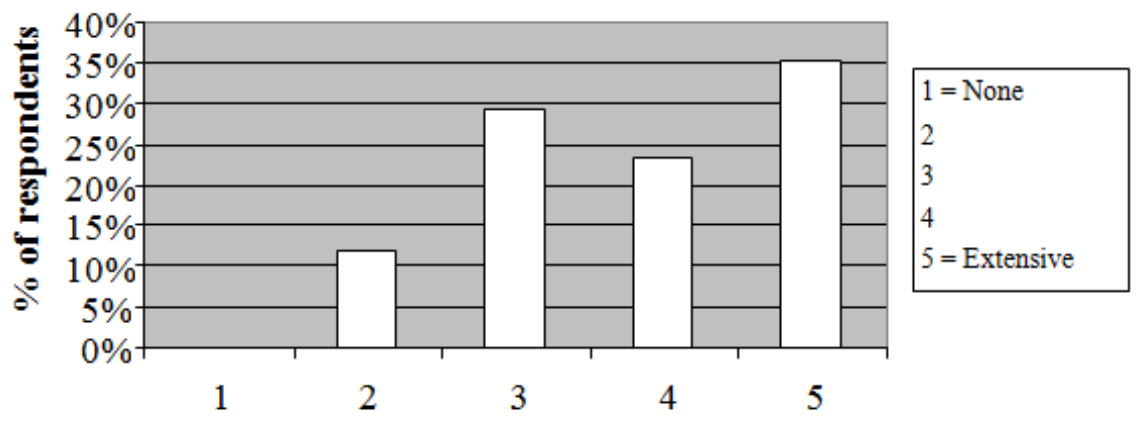


The main issues that were investigated during the due diligence stage included:

- General compliance with local and regional authority’s standards for development including an assessment of the likelihood of gaining consent.

- $\quad$ Services and utilities: infrastructure, upgrades.

- $\quad$ Preliminary scheme plan including the potential number of sections.

- $\quad$ Potential site contamination issues.

- Development costs including: earthworks, roading and services

- $\quad$ Risk assessment.

- Thorough financial analysis (including sensitivity analysis).

- Negotiations with neighbours to ensure access to property.

- $\quad$ Traffic report.

- Market evaluation.

- Accessibility.

When asked whether due diligence could have been carried out more effectively, 61\% of respondents believed if more issues had been looked at, it would have made a difference to the development project. Issues that should have been more thoroughly investigated included:

- $\quad$ Risk associated with having a significant number of adjoining owners likely to object.

- $\quad$ More preliminary discussions with the local authority.

- Depth of the market and sensitivity of pricing including the likely sale prices.

- More geotechnical analysis would have of identified the presence of unsuitable soil.

On three of the four projects, further due diligence could have identified a number of issues that later had an influence on the projects during the development phase. Respondents from one project believed the due diligence was satisfactory.

\section{Development financing}

The sources of finance and the relative proportions employed in the case studies are shown in Table 3. 
Table 3: Source and relative proportion of finance

\begin{tabular}{llll}
\hline Source of finance & $\begin{array}{l}\mathbf{1}^{\text {st }} \text { tier, } \mathbf{2}^{\text {nd }} \text { tier } \\
\text { or mezzanine }\end{array}$ & $\begin{array}{l}\text { Proportion } \\
\text { total funding }\end{array}$ \\
\hline Project 1 & Main trading banks & $1^{\text {st }}$ tier & $50 \%$ \\
& Finance company & $2^{\text {nd }}$ tier & $30 \%$ \\
& Shareholder equity unsecured & & $20 \%$ \\
\hline Project 2 & Investor funds & $1^{\text {st }}$ tier & $25 \%$ \\
& Shareholder equity secured & $2^{\text {nd }}$ tier & $25 \%$ \\
& Shareholder equity unsecured & & $50 \%$ \\
\hline Project 3 & Main trading banks & $1^{\text {st }}$ tier & $80 \%$ \\
& Shareholder equity unsecured & & $20 \%$ \\
\hline Project 4 & Main trading banks & $1^{\text {st }}$ tier & $60 \%$ \\
& Finance company & $2^{\text {nd }}$ tier & $20 \%$ \\
& Shareholder equity & & $10 \%$ \\
& Secured & & $10 \%$ \\
\hline & Shareholder equity unsecured & & \\
\hline
\end{tabular}

None of the projects surveyed offered annuity payments to shareholders or investors; returns were simply by way of profit at the completion of the project. Typically, the developer will source unsecured funds from willing investors providing a guaranteed return and a set repayment date. Interest usually ranges from $15 \%-20 \%$. The investors are not provided with any form of security other than the personal guarantees of the development company's directors. In two of the four projects, a finance broker was engaged to arrange finance on behalf of the development company. In both cases, the respondents suggested some value was added in using a broker, but in both cases the cost versus the benefit was questionable.

The forms of security used were predominately $1^{\text {st }}$ and $2^{\text {nd }}$ ranking mortgages over the development properties. All but one project also had personal guarantees from the shareholders and directors.

In the case of three projects, joint venture (JV) companies were formed as a means of raising finance via an equity contribution from the new JV partner. The proportion of funds raised in this manner ranged from $20 \%$ to $75 \%$ of total project finance. Generally, JV partners were also brought into the project for the skills they possessed including business net works and management skills.

Figure 5 illustrates the relative influence the joint venture partner had, in terms of management decisions, from the perspective of the respondents. 


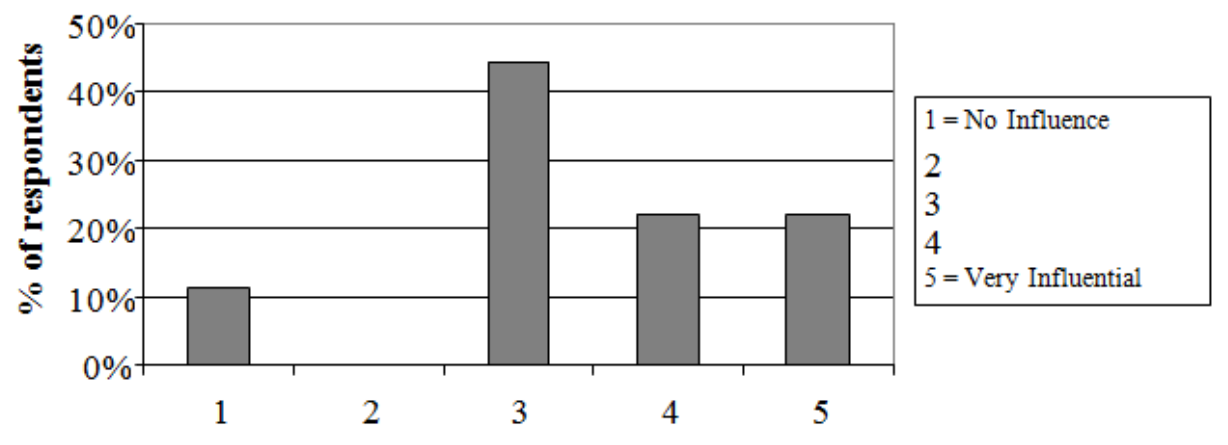

Extent of influence

It can be seen the JV partners generally had a significant influence over management systems and decision making. In all cases, the JV partners did not provide security such as personal guarantees and/or alternate assets over which mortgages could be placed.

The costs of finance were identified by respondents as:

- $\quad$ Lenders fees ranging from $1-2 \%$ of total funding

- Brokers fees ranging from $0.5 \%-1 \%$ of total funding

- Interest costs which were either:

- $\quad$ Capitalised (where interest is compounded daily)

- $\quad$ Paid monthly

- Extension fees when a loan matures and is required to be extended (ranged from $0.5 \%-2 \%$ of the total loan facility being extended)

- Cost of obtaining relevant information a lender may require including valuation reports and due diligence reports

- Legal costs associated with the preparation of lending documentation and registration of securities against assets e.g. the development properties

- Another cost a lender may impose is a non-performance fee. This may be imposed if the developer has requested a number of extensions and the project is taking much longer than the time frames provided for in the original finance 
application. The amount of this fee varies from lender to lender but can be substantial and is designed to ensure the developer makes all efforts to ensure the loan is repaid as soon as possible.

Respondents were asked to give their opinion on the level of importance a lender places on different aspects when assessing a loan application for a development project. Table 4 sets out the results.

Table 4: Lender's assessment of loan applications

\begin{tabular}{llllll}
\hline & $\mathbf{1}$ & $\mathbf{2}$ & $\mathbf{3}$ & $\mathbf{4}$ & $\mathbf{5}$ \\
Aspect & Unimportant & & & Critical \\
\hline General property information & $0 \%$ & $0 \%$ & $17 \%$ & $75 \%$ & $8 \%$ \\
Detailed property description & $0 \%$ & $0 \%$ & $17 \%$ & $83 \%$ & $0 \%$ \\
Property Income & $0 \%$ & $42 \%$ & $8 \%$ & $42 \%$ & $8 \%$ \\
Current market value & $0 \%$ & $0 \%$ & $8 \%$ & $25 \%$ & $67 \%$ \\
Use of the funds & $0 \%$ & $0 \%$ & $25 \%$ & $58 \%$ & $17 \%$ \\
Applicant background & $0 \%$ & $0 \%$ & $33 \%$ & $42 \%$ & $25 \%$ \\
Security offered & $0 \%$ & $0 \%$ & $0 \%$ & $42 \%$ & $58 \%$ \\
Management & $0 \%$ & $0 \%$ & $58 \%$ & $42 \%$ & $0 \%$ \\
Exit strategy & $8 \%$ & $8 \%$ & $25 \%$ & $50 \%$ & $8 \%$ \\
Valuation reports & $0 \%$ & $0 \%$ & $0 \%$ & $58 \%$ & $42 \%$ \\
Sale \& purchase agreements & $0 \%$ & $0 \%$ & $40 \%$ & $30 \%$ & $30 \%$ \\
JV agreements & $0 \%$ & $33 \%$ & $42 \%$ & $25 \%$ & $0 \%$ \\
Development company's registration & $10 \%$ & $20 \%$ & $20 \%$ & $50 \%$ & $0 \%$ \\
Applicant(s) statement of position & $8 \%$ & $0 \%$ & $0 \%$ & $50 \%$ & $42 \%$ \\
Locality & $0 \%$ & $17 \%$ & $50 \%$ & $33 \%$ & $0 \%$ \\
Credit checks on applicant(s) & $0 \%$ & $0 \%$ & $0 \%$ & $83 \%$ & $17 \%$ \\
\hline
\end{tabular}

There is a relatively significant spread regarding aspects such as income the property is generating, exit strategy, joint venture arrangements and whether the developer has secured any sale and purchase agreements. Aspects which have more obvious trends include the provision of valuation reports and the current market value of the subject property; with $92 \%$ of respondents rating the current market value as being important (rating of 4) or critical (rating of 5). All respondents regard being able to actually provide valuation reports as evidence of current market value as very important or critical. Other important aspects to the lender include a statement of the applicants' financial position. Finally, credit checks on the applicant are also important to a lender with $100 \%$ of respondents giving this a high level of importance. 


\section{Relevant legislation and the regulatory process}

Respondents were asked to list the relevant legislation and regulatory processes that apply when undertaking a land subdivision development. Respondents were then asked to comment about whether they believed this legislation was appropriate and how important it is for the developer to forge a strong relationship with the regulatory bodies.

The following legislation and regulations/standards were identified as being relevant to land development in New Zealand:

- $\quad$ The Resource Management Act 1991

- $\quad$ The Land Transfer Act 1952

- $\quad$ The Health and Safety Act 1992

- $\quad$ The Building Act 1991

- $\quad$ The Reserves Act 1977

- The Local Government Act 1974 (and more recently 2002)

- The Property Law Act 1952

- Local and Regional Authority District Plans

- $\quad$ NZ Standards for subdivision and earthworks

- Health Department guidelines

- Urban Design protocols

On the appropriateness of the legislation and regulatory process, respondents provided significant commentary. Some examples include:

- "Land development needs to be carefully managed to ensure adequate protection for people and property along with the environment and other wider factors. Whilst in general the development of land is appropriately governed, there are instances where the current processes are abused, both by developers and those wishing to limit development."

- "The Resource Management Act deals with level of effects which places the onus on the developer to provide a robust case and solutions of how these effects due to the development will be avoided, remedied or mitigated."

- "The legislation and regulatory process is appropriate, but there needs to be improvement in transparency and timing of the process."

The respondents were then asked to describe how the development design and process was managed to ensure compliance was achieved. Typical comments included: 
- "Planning and landscape assessments were done. Council officers were consulted. Expert professionals were part of the team. Design was carried out by experienced professionals with a sound knowledge of codes of practice and planning rules.”

- "Scoping of project against Resource Management Act requirements and level of consent ability."

- "The development policies to ensure they are clearly defined - professional landscape designers were utilised to ensure the criteria was met in the design of the development."

The relationship between the developer and the local authorities was explored and respondents were asked to comment about how they believed good relationships could be forged to ensure both parties work effectively together.

- "Open discussion on the local authority's vision for the long term should be had to ensure the development and its design is aligned with this vision."

- "Local authority officers having more delegated authority would be helpful to streamline the process and avoid unnecessary delays."

- "Better information flow in both directions throughout the application process. Greater availability of all relevant local authority officers is required to meet and discuss proposals during the early stages."

- "Regular meetings and discussions with local authority are needed with the aim of getting them as allies not enemies. The developer should show their face in front of the local authority as much as possible to develop the relationship."

- "A better understanding by the local authority of financial and market constraints would be useful so they can better appreciate the implications of their decisions and the effect delays have on the development project."

The respondents were asked to comment on the extent to which consultation with affected parties was carried out. Figure 6 shows the results: 
Figure 6: Extent of consultation with affected parties

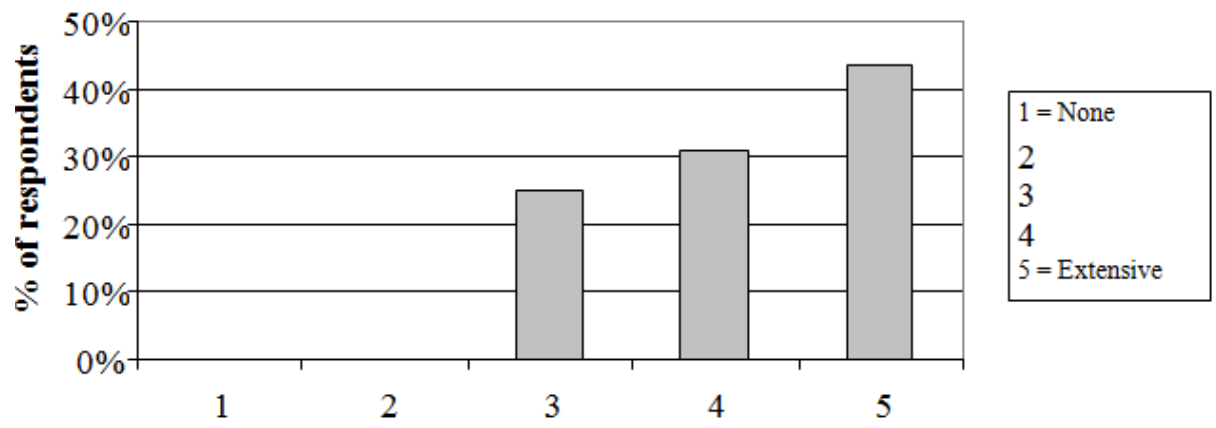

Additional comments included:

- "The level of consultation is dictated by whether the consent application is required to be publicly notified or not. If publicly notified, there are far more parties who could potentially object due to believing they are a directly affected party. Consultation on a wider basis is very important when a consent application is publicly notified. The development team must consider this when designing a development that does not fit within a District Plan's interpretation of being a permitted activity i.e. resulting in a publicly notified consent application."

Figure 7 illustrates to what extent this consultation was perceived as having an influence on the final decision to grant consent and the nature of consent conditions imposed on the project.

Figure 7: Influence consultation had on the consent decision

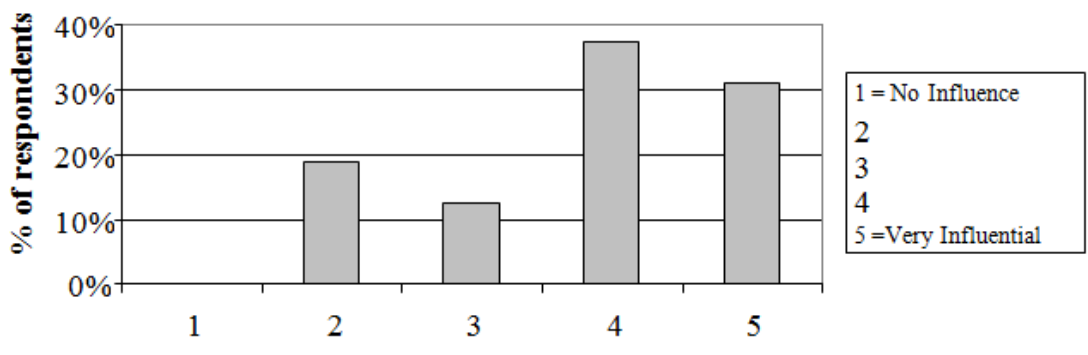

Extent of influence 
$69 \%$ of respondents believed consultation had a significant influence on the final decision made by the local authority and the conditions imposed. This influence wasn't necessarily positive as the conditions imposed may be reflective of the requirements to address the concerns of affected parties. However, this was necessary to gain agreement with affected parties allowing the development to proceed.

19\% of respondents (all from Project 4) believed the consultation process had little bearing on the consent decision. These respondents were the same group who rated the level of consultation in Figure 6 as moderate (rating of 3).

\section{CONCLUSIONS}

Comparisons are made below between the research findings and the literature review in order conclude whether adhering (or not) to theoretical processes actually has a significant effect on relative success of a development in New Zealand.

\section{Measuring success}

The research shows that there were clear elements of success most respondents deemed important and these centered on profitability, timeframes and budgets. While community acceptance, professional satisfaction and mitigation of environmental effects were also considered important, there is a "commercial reality factor" present and a balance that needs to be struck between these (sometimes conflicting) measurements.

For example, gaining complete acceptance by the community may cost too much to achieve. A land development project can be very expensive and may mean the success or failure of a company. Therefore, while it is important to achieve a balance when measuring the various elements of success, there are clearly some elements that are likely to take priority over others from the perspective of the development company.

\section{Site selection}

The literature review emphasised that market research is required to accurately identify trends in demand and supply and help the developer make decisions concerning site, design, section numbers, size and timing. While there are many sources of information available in New Zealand, the task of carrying out extensive investigations can be costly and it appears that in-depth analysis is left until the due diligence stage.

While the site selection factors usually investigated are similar to those identified in the literature review, the extent to which they are investigated and where the information originates from is somewhat different in a New Zealand context. The analysis of statistical information is less relied on, with more importance being placed on the opinions of experienced local professionals such as real estate agents, valuers 
and development partners. However, the most emphasis regarding site suitability is placed on the developer's own experience and the experience of the project team.

Consultation with local authorities is undertaken on a lesser scale; partly due to the reluctance, of local authorities to commit to preliminary development ideas without extensive information being provided. As a result, there is a reluctance to commit funds to the gathering of this information without having secured the site. Once secured, these investigations are more of a due diligence exercise than preliminary site selection.

In determining whether site selection is a critical success factor, the research suggests the more critical factor is the due diligence stage. However, while not necessarily critical, site selection investigations could save time and money if an effective investigation system is established that can easily identify potential development opportunities.

\section{Due diligence}

Far more resources are put into investigations during the due diligence stage. Those issues actually investigated in practice generally reflect those identified in the literature review. Problems which may occur due to inadequate due diligence investigations included: delays in achieving resource consent, increased construction costs, over pricing resulting in a need to later reduce asking prices, choosing an ineffective sales methodology and a lack of appreciation for the depth and sustainability of the market.

While it appears that most of these problems are in fact investigated, the extent can vary due to a number of factors such as:

- Time - There can be a restriction on the period of time required to declare a sale and purchase agreement unconditional. Therefore the developer must decide on the most important issues that need to be investigated when time is limited.

- Cost - If a relatively new company, costs are high and revenues are low. Therefore, some risk taking is necessary in order to progress without outlaying too much money before the decision to proceed is made.

- Experience - If investigations rely on people without the appropriate experience, then inaccurate information may result. A development may elect to employ an inexperienced person to carry out investigations due to the above factors working against them i.e. time (not enough time to get a better qualified professional) and cost (cost of better qualified professionals being prohibitive). 
Due diligence is certainly a critical success factor in land development. Poor due diligence will result in inaccurate information which may lead to delays, increased costs, frustrated project team members, a lack of support from both the local authorities and the community; all of which, may result in development failure.

\section{Development financing}

Sources of finance for land development projects can come in a variety of forms; each having its own rules, covenants, costs and risks. The optimal combination will depend on factors specific to both the developer and the development. The primary source of funding in both the literature review and the survey was bank debt, but there appear to be a wider range of sources of development finance overseas than in New Zealand. For the survey respondents, the sources in 2006 were limited to banks, finance companies, shareholders and joint venture partners.

Financing of land development can be separated into two main areas:

- $\quad$ The initial land purchase and;

- The further financing of development costs.

Lenders offering less expensive sources of debt funding (e.g. trading banks) may not be willing to lend for development costs during the early stages of a development; e.g. before resource consent or pre-sales have been achieved. While relatively speaking, the cost to achieve resource consent is usually a small percentage of the overall project cost, this can still be significant. These funds may need to be obtained from the developer or other equity sources, particularly where there exists a high level of uncertainty.

The literature review and research findings both identified that attributes such as reputation, relationships, track record and financial resources determine the options which may be available to the developer. The loan to value ratio is also a critical consideration.

The literature and survey results were also similar in that debt financing exists primarily in the form of mortgages, further divided into $1^{\text {st }}$ tier, $2^{\text {nd }}$ tier and mezzanine lending - the associated costs increasing between these options. Mezzanine lending is generally used when less expensive options will not consider the project due to high levels of risk. Mezzanine lending can be very expensive and can carry with it a number of onerous covenants. This may include the lender converting their debt to an equity position with the option to take management control and effective ownership of the development in the event of a default. 
Both the literature review and the research identified a number of additional costs of finance in addition to interest. These included establishment fees, extension or penalty fees, broker fees, guarantee fees, and valuation and legal fees.

Joint Venture partnerships were an important source of equity funding, but the details of the partnership agreements varied from project to project and can be complex. The research also confirmed the findings in the literature review that those aspects which are considered in forming a JV partnership include:

- Ensuring the goals and objectives of each partner are aligned.

- Agreement on the likely timeframe of the project and exit strategy.

- Financial contributions.

- Management contribution.

- Delegated authority.

- Profit share proportions and performance fees.

- Extent of each partners legal and financial liabilities.

The financing of the development is clearly a critical success factor. If the wrong options are taken, the developer can quickly find themselves with very high and unsustainable holding costs which may eventually result in distress and failure of the development.

\section{Relevant legislation and the regulatory process}

A solid understanding of the relevant legislation and regulatory process pertinent to land development is a critical success factor. It is during the due diligence and development planning stages that the developer must identify the level of legislative and regulatory risk, then decide on the extent to which local authorities and communities are involved in design.

The literature review and research found that the Resource Management Act 1991 stands out as the primary legislation impacting on land development in New Zealand. The RMA was found to be generally appropriate legislation; however it is essential that competent and experienced professionals are employed to advise on legal and regulatory implications. Thorough consultation with the community is advisable, as the RMA provides for potentially affected parties to object which may result in delays and significant costs.

It is also advisable to hold early discussions and form good relationships with local authorities. This ensures constructive dialogue is established with far reaching benefits in terms of getting design and consultation right the first time.

In conclusion, it is apparent from both the literature review and survey results that land development requires careful consideration of a significant number of factors. In 
respect of the four categories of factors discussed in this paper, while differences were identified between New Zealand practice and that identified in the literature, these were comparatively minor. Consideration of critical factors should mitigate the risks associated with land development. While each factor is individually important, they must also be considered in relation to each other. Failure to adequately consider an individual success factor may not necessarily equate to failure of a project; however, the carefully planned and implemented combination of all critical factors will result in a truly successful project.

\section{Research limitations}

The research was undertaken using only four case studies. These projects were all undertaken by one development company; albeit in partnerships with external parties and thus also subject to their influence. Therefore, the development processes and systems employed were influenced to varying degrees by the culture of the principal company and the result therefore may not be balanced or especially representative of the land development industry as a whole. However, 21 individuals took part in both interviews and surveys and these professionals spoke from a variety of perspectives and backgrounds. They also had extensive experience of other land development projects, as well as these specific case studies, and this often enhanced their responses. Not all the projects were complete at the time this research was undertaken. However, all projects had sufficiently progressed through the land development process to facilitate meaningful responses.

The questionnaire and interviews contained questions not all respondents could answer due to lack of involvement in particular areas of the development. However, sufficient respondents had the knowledge to provide a range of answers within each section of the questionnaire which helped facilitate meaningful analysis. The answers given to some questions were open-ended and subjective, and dependent on the respondent's personal opinion and experiences. This may result in inconsistencies, but can also be seen as identifying important factors to those involved in the projects and raise issues not anticipated by the researcher.

This research is best seen as exploratory. It appears very little prior research has been undertaken in New Zealand as to what contributes to successful land development, despite the fact that this activity is relatively commonplace. The results of this study could provide a basis for a much more widely distributed survey designed to validate these initial findings. This should include a range of developers in terms of size, experience, property type and location.

\section{REFERENCES}

Arrow International Ltd, Arrow International: Project Development. (No date). Development Planning Guide, Christchurch, pp. 2-30 
Bank of America. (2002). Mezzanine Finance: Closing The Gap Between Debt And Equity. Capital Eyes, October, pp. 1-4.

Christiansen, W. K. S. (Ed). (1996) Fundamentals of Property Management. (2 ${ }^{\text {nd }}$ Ed). Wellington: Butterworths.

Crosby, A. (1994), Implications for Property from Trends in Resource Management, New Zealand Valuers Journal, June, pp. 48-49.

Dowell, D. E. (1989). Making Land Development Work: The Process and Critical Elements for Success. Real Estate Finance, Fall, pp. 15-26.

Gitman, L.J., Juchau, R., Pearson, K., \& Clemens, M. (1995). Principles of Managerial Finance in Australia. New York: Harper Collins Inc.

Guerard, R. (2005). Land Acquisition and Development Finance Part 4. Professional Builder, November, pp. 33-37.

Heimlich, R.E., \& Anderson, W.D. (2001). Development at the urban fringe and beyond: Impacts on argriculture and rural land. Agricultural Economic Report, no. 803. U.S.D.A, pp. 1-8.

Jarchow, S. P. (1991), Graaskamp on Real Estate, Washington: Urban Land Institute.

Loh, P. K. (2003). Mezzanine Finance: The resurgence of an old investment tool. Technopreneurial.com. Electronic Journal [on line]. Retrieved on 24 July, 2006, from http://www.technopreneurial.com

Martin, W. B. (1984), How to Predict Urban Growth Paths, The Appraisal Journal, April, pp 424-429.

Pearson, T .D. (1991), Location! Location! Location! What is Location?, The Appraisal Journal, January, pp. 7-20.

Peiser, R .B. \& Schwanke, D. (1992) Professional Real Estate Development. Washington: Dearbon Financial Publishing Inc. and the Urban Land Institute.

Rae, B. (1999), Healer Heal Thyself? A Strategic Approach To RMA Issues, The Property Business, Issue no. 3, pp. 50.

Rowland, P.J. (1993). Property investments and their financing. Sydney: The Law Book Company Limited. 
Sorenson, R C. (1990). Project Management: Success or Failure? The Appraisal Journal, April, pp. 147-152.

Waterhouse, M. D. (1991). Principles of the Real Estate Development Process. Economic Development Review, Fall, pp. 25-28.

\section{Email contact: john.mcdonagh@lincoln.ac.nz}

